\title{
Counseling as a Method of Psychological Reconciliation for Victims of Dating Violence ${ }^{1}$
}

\author{
Inosensius Tomi Kristoper', Sutarto Wijono², Jacob Daan Engel ${ }^{3}$ \\ 1,2Faculty of Psychology, ${ }^{3}$ Faculty of Theology, Universitas Kristen Satya Wacana
}

\begin{abstract}
Dating violence (DV) has psychological impacts on the victims such as depression, trauma, anxiety, decreased self-esteem and feeling of resentment. This article aims to rediscuss the process of reconciliation and its relationship to DV victims' inner peace. The process of psychological reconciliation would help to set the victims free from the shackle of previous abusive dating relationship. Reconciliation is defined as being able to cultivate peace within oneself. Because the victims' problem lied in the memory of abusive experiences conducted by the violent doer, one of the proposed effective techniques that can be used in psychological reconciliation is counseling for DV victims.
\end{abstract}

Keywords: counselling; dating violence; reconciliation

\section{Introduction}

Violence toward partner in a relationship or dating violence in relationship is one of the phenomena that is often experienced by adolescents and young adults. World Health Organization (2017), defined Dating Violence (DV) as violent behavior towards dating partner with a form of violence that is ranging from physical, sexual, to psychological in nature. The Ministry of Women's Empowerment and Child Protection of the Republic of Indonesia (2018), also defined DV as an incident of violence that occurs in couples who are dating and that violence consists

\footnotetext{
* Addres for corespondence:

${ }^{1}$ tomikristoper01@gmail.com

${ }^{2}$ wijonosutarto@gmail.com,

3jopie_engel@yahoo.com

${ }^{1}$ This paper is part of the literature review of the Post-Grants Grants from DRPM-Kemenrisetdikti with the title Model Prevention and Protection of Violence in Gender-Based Dating From the Integrative Holistic Psycho-Ecological Perspective in Central Java in the third year of a 3-year plan, in 2018.
}

of physical violence, psychological violence, economic violence and behavioral restrictions. World Health Organization (2013) revealed that women victims of DV are twice as likely to experience violence that will result in depression and mortality (42\%), compared to women who do not experience DV. World Health Organization (2017), revealed "almost 30\% of women who have dated had hapless or unfortunate experiences of physical violence and sexual violence".

Factors causing violence that also often cause DV are; erroneous knowledge and understanding of the concept of men who are more dominant in the social system (patriarchy), frequent use of narcotics, alcohol consumption, and promiscuity, inability to control emotion, an affair done by one of the partners in a relationship, unemployment of one partner, experiencing wrongful parenting during childhood in the form of abuse from parents or witnessing abuse comitted by parents, being hit by poverty, and the impact of violence shown by mass media 
or tv shows (Ministry of PPPARI, 2018). Related to parenting, Putri, Wijono, and Hunga's (2016) research revealed that the tendency of DV victims in developing insecure patterns is obtained from the past from both parents. DV victim grows in an ambivalent-insecure pattern that tends to be developed by the couple so that DV victim prefers to stay in relationship, because the victim develops acute anxiety when having to be separated from his or her partner. Another cause concluded in the Landor, Hurt, Futris, Barton, McElroy, and Sheats' (2017) study was that women often do the beatings first and are reciprocated by their partners who also do not like to be treated harshly. Events like this show the dual role of both parties, DV victim changes role as violent doer.

In addition, there are needs that must be met by women who experience insecure attachment patterns such as physical touch from their partner, feelings of emotional touch such as hearing "I love you", and affection from a partner. Those needs are often used by DV doers to treat their victims as they wish such as by committing violence. This is done by the violence doers on the ground of "love" which often blinds DV victims to think that the action is reasonable so that DV victims resign themselves to receive violent treatments (Putri et al., 2016). The same thing was expressed by the Ministry of PPPARI (2018), there were other things that caused DV namely, women as victims of DV were helpless, lacked selfconfidence, and feeling excessive love for a partner. This is because the offender tends to behave affectionately after committing violence. The violent doer shows remorse, always wants to be forgiven, and always promises to not repeat the same actions. The treatment of such violence doer makes DV victims weakening easily, forgiving the violence doers, and continuing relationships as normal. The violence doer's habitual patterns are repeated over and over; commiting violence, regretting, apologizing, resuming relationship as usual, repeating it again, so it becomes a cycle of misfortune for victims that is never ending (Murray, 2007).

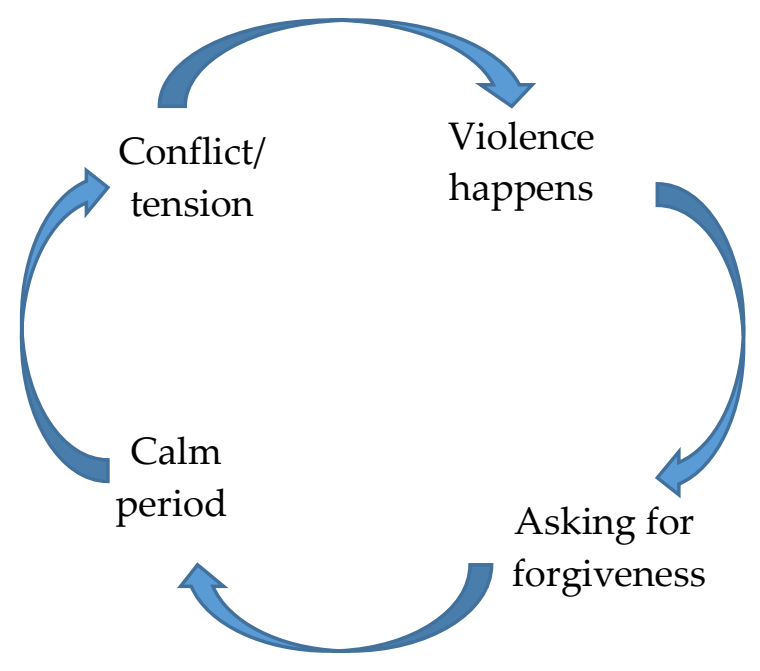

Figure 1. Cycle of dating violence (Murray, 2007)

Research by Witte, Kopkin, and Hollis (2015), revealed that alcoholic drinks are often consumed by violence doer before committing violence'. The influence of alcohol makes violent doer physically abuses and intentionally injures the victim. Kaukinen, Buchanan, and Gover (2015), revealed that 'the beginning of the hapless or unfortunate experience of DV victim comes from the violent behavior that is received from their parents'. Furthermore, according to Kaukinen et al. (2015), this experience influences the views and mindsets of victim and offender in DV about how to treat others. Besides that, violence can also be a revenge attempt of doer in DV for their bitterness. Revenge is done solely for satisfaction and venting negative emotions such as anger and 
others. However, it becomes a cycle of violence that never ends which made doer in DV continues to behave violently and look for other victims. A similar sentiment was expressed by Al-Modallal (2016), who identified the experience of the violence doer during childhood such as; victims of physical violence (19.6\%), victims of sexual violence $(11.3 \%)$, victims of psychological violence $(35.1 \%)$, witnessed mothers abusing fathers $(9.3 \%)$, and had witnessed fathers abusing mothers (34\%)).

If identified, every cause of DV that has occurred in adolescence to early adulthood is often due to the hapless or unfortunate past experiences of the offender during childhood (Webel \& Galtung, 2007). These experiences influence the mindset in behaving and treating other people or their partners. In addition, the behaviors of DV doers are influenced by alcohol and illegal drugs, so that they often unconsciously commit violence to their partners. However, violence doer's victims more often endure the violence. The same reason was stated by Talise, Wijono, and Hunga (2016), love also makes violence doer's victims unable to objectively assess the situation they are in and this can slowly change the personality of the victims. In addition, when parents as role models often showed violent behaviors and hurt one another, serious impact can be seen in the dating lives of DV victims and doers (Putri et al., 2016). The experience of witnessing their parents abusing each other made victim and DV doer assuming that in establishing a relationship, it is natural if partner is perpetrating violence.

Therefore, further into this article, the author will review and explain the psychological impact experienced by DV victims, counseling therapy for selfreconciliation of victims, and the effect of reconciliation counseling on the psychological condition of victims. The purpose of this article is to review the reconciliation process and its impact on the psychological peace of DV victims.

\section{Discussion}

\section{Psychological Impact on Victims of Dating Violence}

Various impacts of violence that are often experienced by DV victims include physical, reproductive health, sexual, and psychological impacts (World Health Organization, 2017). The psychological impact of DV victims can take form in anxiety, depression, symptoms of depression, trauma, decreased self-confidence, constant negative thoughts, desire for revenge, and irritability (Collibee et al., 2018). Even after separation, the impact can still be felt by DV victims and their freedom will be taken away by bitter experiences in the past (Landor et al., 2017).

After separating from the violence doer, the unfortunate past experience remains in the memory of DV victims (LeDoux, 2010). The memory of bitter experiences often arises suddenly which can disturb the psychology of DV victims. The appearance of that memory causes unexpected reactions. These reactions may include unstable emotions which cause anger or irritability, psychological turmoil, crying and feeling sad easily, inferiority, and hopelessness (Geldard \& Geldard, 2003). In addition, DV victims can retaliate by perpetuating similar kind of violence toward their partners (Albin, 2007).

Tussey, Tyler, and Simons (2018), revealed the impacts experienced by DV victims also include constant anxiety, having the desire to consume alcohol, 
abusing drugs and practicing unsafe sex. Yalch, Lannert, Hopwood, and Levendosky (2013), also revealed that 'dating violence victims have tendency to experience anxiety and depression'. Anxiety and trauma are immediately felt by the victim when he/she receives abuse by violent partner. The feelings evoke negative behaviors such as free sex, alcohol consumption and illegal drugs use (World Health Organization, 2013). The impact experienced by each DV victim can create haplessness during dating and even after they separated. Drugs and alcohol consumptions are done to vent out negative feelings and forget their bitter experience. The haplessness of DV victims may incite grudge toward their violent partners (Muller-Fahrenholz, 1997).

Psychologically, DV victims would feel that what they are experiencing is hapless or unfortunate. Often bitter experiences such as hatred are buried for too long in DV victims (MullerFahrenholz, 1997). Lederach (1997), stated that every individual who is a victim of violence will experience hurt, anger, sadness, loss of hope, hatred toward the opposite sex, and prolonged trauma. This experience will continue to emerge and is always present in the daily lives of victims. The bitter experience of getting abused by the perpetrators can automatically stimulate DV victims. According to Lederach, the stimulus can be transformed into negative emotions such as anger that victims may attack or injure people around them. Psychological changes can occur drastically when painful and unfortunate past memories appear suddenly (Ehlers \& Clark, 2000).

A hidden hapless or unfortunate memory can shackle the freedom of DV victims. The cycle of violence in dating relationships will be difficult to break and dating violence victims experience haplessness every day. The possibility of victims turning into offenders cannot be ruled out as well because they may have the desire to vent their hurt to others. The impact of the action can cause new victims so that the cycle will repeat itself (Parker, Johnson, Debnam, Milam, \& Bradshaw, 2017). This can happen because humans will not be satisfied and in peace if others have not tasted the bitterness they felt (Muller-Fahrenholz, 1997). This happens continuously in the daily lives of adolescents and can recur when they have a family (Talise et al., 2016). In other cases, DV victims can also continue to be victims and receive wrongful treatment by different violence doers in relationships. This is a form of ongoing denial about the violent treatment, causing DV victims to experience long term hurt and trauma (Ehlers \& Clark, 2000; Muller-Fahrenholz, 1997).

When an individual becomes a DV victim, he/she will not be willing to share the unfortunate past experience with anyone. It is considered a disgrace, and victims will feel ashamed if others find out (Ministry of PPPARI, 2018). If the situation gets to irresponsible people, negative judgment and different treatment (discrimination, bullying and being ignored) might be done by friend and victims can also be ostracized from social situations (World Health Organization, 2013). It will also add social pressure, stress, depression, etc., which lead to more hapless or unfortunate experiences. Bullying for DV victims who have maladaptive coping mechanism can result in development of mental illness and even suicide (Muller-Fahrenholz, 1997; Webel \& Galtung, 2007). Therefore DV victims prefer to hide their violent experiences (Hanh, 2015). However, the tendency to 
hide their unfortunate experiences can cause tension and inner conflicts when consciously memories of hapless or unfortunate past experiences arise. The problem of DV victims lies in their emotional disturbance due to the presence negative memories (Muller-Fahrenholz, 1997). According to Albin (2007), anger and hatred can arise in response to past experiences. Conflict or tension within individual can be caused by different emotional reation. Psychoanalysts estimate that each victim of violence will spend up to $50 \%$ of their mental and emotional energy suppressing painful memories (Gass, 2004).

Violent treatment by DV doer becomes one of the active memories ingrained and accessible to the conscious memories of DV victims in the future (LeDoux, 2010). On the other hand, memories also work outside of awareness and control behavior without the victim's conscience. Past memories shape the emotional experience of DV victims and when memories are consciously accessed by victims which will cause temperamental behavior or other kinds of behaviors (Ehlers \& Clark, 2000). Similarly, the research of $\mathrm{Li}$, Rovenpor, and Leidner (2016), revealed that emotional experiences are the main causes of anger for victims of personal violence. These emotions often cannot be controlled by individual. Thus, emotional regulation plays an important role in maintaining one's condition (Shnabel \& Ullrich, 2016).

\section{Counseling as a Method of Self Reconciliation Victims of Violence in Dating}

Before describing counseling as a method of reconciliation, the meaning of reconciliation will be explained. First, the meaning of reconciliation according to Webel and Galtung (2007), is the stage of self-recovery (restoration) for victims of violence and also mending relationship with the perpetrators to peaceful direction. The victim's peace of mind will lead them to a peaceful and thriving future. The description by Webel and Galtung provides an understanding that reconciliation facilitates peace in victim's psychological state. Reconciliation can also facilitate relationship recovery between victim and violence doer (Webel \& Galtung, 2007).

Meanwhile, according to Lederach (1997), reconciliation is a space provided to reconcile victim and violence doer by bringing them together. According to Lederach, the two are reunited after the victim is truly able to forgive and the violence doer is willing to admit his/her mistakes. According to Lederach, both are required to have a commitment in improving themselves and their relationships with each other.

According to Hanh (2015), reconciliation can also mean managing the peaceful state within and releasing bitterness. Reconciliation is against desires to punish perpetrators. According to Hanh, reconciliation may only happen within oneself, victim does not have to always mend relationship with the violence doer, but most importantly is able to let go of hatred, grudge, and bitterness of the past without having to meet with the perpetrators again.

There are differences between the three opinions. Lederach's opinion emphasizes recovery of the relationship between the victim and violence doer. Both parties need to be brought together in one place to resolve conflict between each other. Whereas, the opinion of Webel and Galtung (2007) emphasizes the focus of victim's self-recovery and freeing victims from memories of hapless or unfortunate experiences, so that victims get peaceful 
state of mind in the future. In addition, Webel and Galtung also explained the psychology of peace, which is oriented more to the psychological peace of victims. A similar opinion was expressed by Hanh regarding reconciliation oriented toward Buddhism. According to Hanh, the reconciliation process does not have to bring victims and perpetrators together. However, reconciliation must occur within the victim's self, so that the victim can experience peace in himself/herself. Selfreconciliation is intended so that victims can also forgive the perpetrators personally.

Based on the definitions of reconciliation from three experts above, the conclusion is that reconciliation is a strategy to set the DV victims free from the shackle of unfortunate experiences in the past and make peace with themselves, to live a future life with peaceful psychological state. The most important thing is that reconciliation does not only aim to bring together and reconcile two parties in conflict (Hanh, 2015). The reconciliation process will be more useful when both have the awareness to improve themselves and also improve their relationships. However, if only one is willing and has the awareness to make peace, that will not be an obstacle or problem (Hanh, 2015). The role of DV victims alone is no less important to change the stubborness of perpetrators to realize their mistakes and ask for forgiveness willingly (Hanh, 2015; Webel \& Galtung, 2007). Osho (2008), stated that it is not good if every DV victim controls or represses negative emotions because they can explode suddenly and the situation would be more difficult to control. Thus the victims can turn into perpetrators of dating or domestic violence, criminals and public law offenders (Winch, 2017). Čehajić-
Clancy, Goldenberg, Gross, and Halperin (2016), stated that the process of reconciliation has an influence on emotion regulation according to psycho-social perspective. Emotion regulation helps the victims in managing themselves and selecting external stimuli.

Thus, every DV victim must let go of unfortunate past experiences ever be felt. Victims have the right to feel peace within themselves. Letting go of unfortunate experiences in the past can promote freedom and peace in the future for DV victims (Muller-Fahrenholz, 1997; Webel \& Galtung, 2007). Victims need other people who can be trusted to help them finding peace and listening to their woes caringly. Being listened to with care can provide a sense of comfort and security for DV victims so they will be able to share about bitterness in the past (Geldard \& Geldard, 2003). Sharing can be done through direct conversation, writing and singing songs that describe their feelings (Osho, 2008).

DV victims must be facilitated to reconcile with themselves utilizing counseling method with the help of facilitator. Providing assistance to DV victims in solving problems arising from hapless or unfortunate experiences in the past is important. In reality, each DV victim is obstinate and does not feel that he/she has problems (Putri et al., 2016). Another assumption is that they think violence in dating relationships is reasonable (Talise et al., 2016). Such things become obstacles for DV victims to save themselves and experience well-being in the future (Albin, 2007). In addition, DV victims do not have the courage and also feel ashamed to share or consult about their problems. Therefore the keys to freedom of DV victims are awareness that they must be brave to move forward, vigor to fight the ego that keeps them within 
safe zone, and considering that they have problems (Osho, 2008).

Geldard and Geldard (2003), revealed that counseling is a therapy mode where facilitator listens to the problem carefully. It emphasizes the importance of respecting the client's feelings in order to create a solution together. The objective of this counseling is to help DV victims in examining the maladaptive thoughts that they have previously in accordance to the past negative experience that they truly experienced (Perry, 2010). Maladaptive thoughts usually developed by victim are despair, low self-esteem, suicidal thoughts, desire to avenge and hide their pain. Such maladaptive mindset is replaced by adaptive mindset which can bring peace to DV victims. Counseling is chosen as a method to facilitate emotions. It is also chosen as a cathartic media (in the form of sharing) to let out the unfortunate past experiences while being a DV victim. Victims often think or remember unfortunate past experiences that are torturous. This way of thinking becomes a problem that cannot be solved and left behind by DV victims (Pennebaker, 2002).

The unfortunate past experiences of a DV victim are shared during counseling session with trusted facilitators. The facilitator is a person who is able to listen attentively or can also be a professional counselor (Gladding, 2012). The facilitator should listen carefully to the victim's story and direct the DV victim to the actual reality. Through the sharing, DV victim can let go of negative emotions in bitter past experiences that have been embedded in them for a long time (Musman, 2017). This method is provided to victims so they are willing to share their unfortunate experiences and also use it as a cathartic tool.
The first thing that needs to be done in counseling is setting goals (in this case psychological peace) that will be achieved by the victim and guided by the counselor (Perry, 2010). During the session, victim will bring in a list of unfortunate experiences during the DV. Counselor's task is to listen to every part of the problematic story patiently and carefully (Yeo, 2002). Attentive listening is done to find the reason for persisting problem and solutions to be constructed together (Perry, 2010).

During the therapeutic counseling, DV victim will slowly tell the unfortunate past experiences because there is someone who is going to listen to them. When DV victims are willing to talk about their past experiences, they are utilizing the cathartic opportunity to release negative emotions that have been buried (Geldard \& Geldard, 2003). Regular counseling sessions must be scheduled until DV victim no longer feels disturbed by the memories of unfortunate past experiences. At that time, DV victim can finally feel psychological peace and freedom. However, it does not happen instantly but takes long time. The need for long-term or short-term counseling is determined by the severity of depression or problems experienced by the victim (Geldard \& Geldard, 2011).

In addition, it is important to ask the question "what changes do you want to experience?". The question can foster enthusiasm and motivation in DV victims so they are willing to change themselves (Geldard \& Geldard, 2011). When victims confess their problems, the counselor sees the problem as an effort to adjust to the current living situation. In an effort to deal with the situation, DV victims will exhibit symptomatic behavior such as depression, anxiety or other inappropriate behaviors (Yeo, 2002). Such behaviors give a sign to 
counselor that DV victims are experiencing problems. It provides direction to the counselor to guide and find solutions for DV victims so they can let go of their bad past.

Nelson-Jones (2012), stated that when victim has confessed their problems, it is important for counselors to help DV victims planning activities that will improve psychological well-being (PWB). In addition to talking to counselors during sessions, it would be better if DV victims are also requested to do activities that they like. Leisure activities like writing, singing, exercising in open environment will help DV victims getting rid of their bad past experiences. These activities can help to release negative emotions gradually (Yeo, 2002).

In addition, the role of catharsis in the release of emotions is very helpful in reducing the effect of unfortunate past experiences. Research by Qonitatin, Widyawati, and Asih (2011), showed that there is a very significant cathartic effect of using writing therapy on students who experience mild depression. Writing therapy helps releasing negative emotions related to their experiences and has an impact on reducing depression level. It was found that writing about thoughts and feelings can produce cognitive psychological changes in individual who has unfortunate experiences in the past (Pennebaker, 2002). This method might be beneficial for DV victims.

Pennebaker, revealed more than $70 \%$ clients reported that writing can help them in getting rid of unlucky experiences in the past. Pennebaker, also conveyed the success of writing therapy in changing DV victims' way of thinking so they can have positive mindset. It is a way of expressing emotions about unfortunate past experiences by putting them into a narrative. The victims can share their stories more during writing in addition to counselling sessions. During the cathartic process the victims can feel relief, because the negative emotions are gradually released. However, to get maximum results, counseling should be done regularly until the victims felt peace within themselves (LeDoux, 2010).

In the DV victims counseling process, one should strive to solve the problem that is being experienced by DV victims. Palmer (2012), revealed that problem solving is needed to help victims dealing with their emotional problems, in addition to experiencing happiness and well-being. Problem solving process can be done if DV victims think more rationally. Counselors focus on finding specific and clear information from DV victims to come up with solutions to their emotional problems (Palmer, 2012). Palmer also presented several ways of solving problems. First of all, it involves DV victims' full range of emotions while fighting maladaptive thoughts that harm them. After that, stimulating DV victims to memorize all of bad things they had experienced. The victims will feel sadness and may outwardly cry as if reliving the past episodes. Consequences that can be detrimental to victims' wellbeing if continuing to bury the unfortunate past experiences are then showed. It stimulates the DV victims to imagine his/her future if he/she is willing to let go of the bad experiences. Thus DV victims will get deeper understanding of problems they are facing and change their mindset to be reconciled with their past.

Counseling is a medium that can be used by counselors to solve problems of DV victims. However, its success was determined by the DV victims themselves. The counselor or facilitator only serves as 
an intermediary and guides DV victims towards welfare and peace (Geldard \& Geldard, 2003).

The Effect of Counseling as a Method of Reconciliation on the Negative Psychological Effects of dating violence victims

Research on the influence of counseling by Arumsari (2016), revealed that the application of effective counseling increased the self-control ability of grade 11 students in Vijaya Kusuma. Another study conducted by Saripah (2010) revealed that bullying victims experienced an increase in assertiveness and selfconfidence after receiving cognitive behavioral counseling. Sawangchareon et al. (2013), revealed that women victims of violence significantly felt improved selfesteem and self-evaluations which in turn enhanced their health. After counseling, victims of violence become ready to face the problem and able to make peace with themselves, even more so with the situation they are facing (Engel, 2018). Therefore, counseling can also have an influence on community problems, one of which is DV. However, in Indonesia there are only few counseling services in the regions, making it more difficult for victims to access counselors' aid. In addition, there is a lack of victim's awareness about the violence that occurs. There is also no desire to prevent or overcome the problem.

Research on reconciliation in DV has never been done. This makes it difficult to find references to previous research. However, reconciliation is often done within the context of conflicts between groups and nations. Previous studies can provide an overview of the reconciliation process in past conflicts. Research conducted by Sulaeman (2015) resulted in an analysis that reconciliation can success- fully resolve conflicts by combining modern scientific approaches such as law enforcement, third-party mediation, and socio-economic empowerment of culture. The second approach is local belief such as using "women" as a defense who dares to take the moral and psychological burden for safety and peace.

Other research conducted by Bakri (2015), showed the results of the reconciliation process using the trust of local residents in Ambon, Maluku namely Pela gandong. This cultural approach can mobilize the community to unite by repairing facilities and infrastructure together after being damaged by conflict. Thus, the reconciliation process is a variety of ways to build peace in the society, with culture as one of the modes.

So far, no research has been conducted about psychological counseling for DV victims. Reconciliation has been widely studied, but not in the context of psychological reconciliation for victims of DV and psychological counseling methods for them. Previous studies on reconciliation were mainly conducted on victims and perpetrators of post-communal conflicts. Thus, research on the psychological process toward peacefulness for DV victims with the help of psychological counseling methods needs to be done more. They should emphasize on the psychological reconciliation process and DV victim's peace of mind.

\section{Conclusion}

Currently, studies done on DV can be likened to iceberg phenomenon where only the tip of the iceberg can be seen on the surface, but most is hidden in the sea. Studies on DV victims are mostly about case identification. There are only few studies on DV victims' recovery. Violence 
in relationship resulted in unfortunate experiences for the victims, which stimulated the rise of negative emotions. Negative emotions incite negative reactions in the victims. These reactions may take form of violent behaviors, retaliation toward their partners, and maladaptive coping such as committing suicide.

One of the goals of DV victims' recovery is to have peace within or psychological reconciliation. Studies on reconciliation in DV victims' cases are still very rare. One of the psychological reconciliation strategies for DV victims is counseling. Counseling can facilitate victims in expressing the negative emotions that are hidden. During counselling sessions, victim can slowly get closer toward the state of wellbeing. After that DV victims are likely to forgive the perpetrators without having to meet them and experience peacefulness in the future. However, this process requires a long period of time, not spontaneously. It also requires extensive research. As a suggestion, further case studies of DV victims and reconciliation counseling for the recovery process must be done in Indonesia. That way, the cycle of DV or violence in general can be stopped and recovery for the victims and perpetrators can be promoted.

\section{References}

Al-Modallal, H. (2016). Childhood maltreatment in college women: Effect on severe physical partner violence. Journal of Family Violence, 31(5), 607615. doi: $10.1007 / \mathrm{s} 10896-016-9797-\mathrm{Z}$

Albin, R. S. (2007). Emosi: Bagaimana mengenal, menerima, dan mengarahkannya. Yogyakarta: Kanisius.

Arumsari, C. (2016). Konseling individual dengan teknik modeling simbolis terhadap peningkatan kemampuan kontrol diri. Jurnal Konseling Gusjigang, 2(1), 1-11. doi: $\underline{10.24176 / j k g . v 2 i 1.549}$

Bakri, H. (2015). Resolusi konflik melalui pendekatan kearifan lokal pela gandong di kota Ambon. The Politics: Jurnal Magister Ilmu Politik Universitas Hasanuddin, 1(1), 51-60.

Čehajić-Clancy, S., Goldenberg, A., Gross, J. J., \& Halperin, E. (2016). Socialpsychological interventions for intergroup reconciliation: An emotion regulation perspective. Psychological Inquiry, 27(2), 73-88. doi: 10.1080/ $\underline{1047840 X .2016 .1153945}$

Collibee, C., Rizzo, C. J., Kemp, K., Hood, E., Doucette, H., Gittins Stone, D. I., \& DeJesus, B. (2018). Depressive symptoms moderate dating violence prevention outcomes among adolescent girls. Journal of Interpersonal Violence, Apr 1, 088626051877018. doi: $\underline{10.1177 / 0886260518770189}$

Ehlers, A., \& Clark, D. M. (2000). A cognitive model of posttraumatic stress disorder: Theory and therapy. Behaviour Research and Therapy, 38(October), 321-345.

Engel, J. D. (2018). Konseling masalah masyarakat. Yogyakarta: Kanisius.

Gass, B. (2004). Forgetting your past. Gainesville, USA: Bridge Logos Publisher.

Geldard, K., \& Geldard, D. (2003). Membantu memecahkan masalah orang lain teknik konseling. Yogyakarta: Pustaka Pelajar.

Geldard, K., \& Geldard, D. (2011). Keterampilan praktik konseling: Pendekatan integratif. Yogyakarta: Pustaka Pelajar.

Gladding, S. (2012). Konseling: Profesi yang 
menyeluruh. Jakarta Barat: Indeks.

Hanh, T. N. (2015). Rekonsiliasi: Menyembuhkan anak kecil dalam diri sendiri. Jakarta: Karaniya.

Kaukinen, C., Buchanan, L., \& Gover, A. R. (2015). Child abuse and the experience of violence in college dating relationships: Examining the moderating effect of gender and race. Journal of Family Violence, 30(8), 1079-1092. doi: $\underline{10.1007 / s 10896-015-9731-9}$

Kementerian Pemberdayaan Perempuan dan Perlindungan Anak Republik Indonesia. (2018). Waspada bahaya kekerasan dalam pacaran. Retrieved March 22, 2018, from Kementerian Pemberdayaan Perempuan dan Perlindungan Anak Republik Indonesia website https://www.kemenpppa.go. id/index.php/page/read/31/1669/was pada-bahaya-kekerasan-dalampacaran\#

Landor, A. M., Hurt, T. R., Futris, T., Barton, A. W., McElroy, S. E., \& Sheats, K. (2017). Relationship contexts as sources of socialization: An exploration of intimate partner violence experiences of economically disadvantaged African American adolescents. Journal of Child and Family Studies, 26(5), 1274-1284. doi: 10.1007/s10826-016-0650-Z

Lederach, J. P. (1997). Building peace: Sustainable reconciliation in divided societies. Washington, DC: United States Istitute of Peace.

LeDoux, J. (2010). The emotional brain. Yogyakarta-Surabaya: Baca.

Li, M., Rovenpor, D. R., \& Leidner, B. (2016). Regulating the scope of an emotion regulation perspective on intergroup reconciliation. Psychological Inquiry, 27(2), 117-123. doi: 10.1080/ $\underline{1047840 x .2016 .1163960}$
Muller-Fahrenholz, G. (1997). The art of forgiveness: Theological reflection on healing and reconciliation. Jeneva: WCC Publication.

Murray, J. (2007). But $i$ love him. HarperCollins e-book.

Musman, A. (2017). Berdamai dengan emosi. Yogyakarta: Psikologi Corner.

Nelson-Jones, R. (2012). Pengantar keterampilan konseling: Kata dan tindakan. Yogyakarta: Pustaka Pelajar.

Osho. (2008). Emotional learning. Yogyakarta-Surabaya: Pustaka Pelajar.

Palmer, S. (2012). Konseling dan psikoterapi. Yogyakarta: Pustaka Pelajar.

Parker, E. M., Johnson, S. L., Debnam, K. J., Milam, A. J., \& Bradshaw, C. P. (2017). Teen dating violence victimization among high school students: A multilevel analysis of school-level risk factors. Journal of School Health, 87(9), 696-704. doi: 10.1111/josh.12538

Pennebaker, J. W. (2002). Ketika diam bukan emas: Berbicara dan menulis sebagai terapi. Bandung: Mizan.

Perry, W. (2010). Dasar-dasar teknik konseling. Yogyakarta: Pustaka Pelajar.

Putri, N. R. P. N., Wijono, S., \& Hunga, I. (2016). "Paradoks cinta: Antara pengorbanan dan perpisahan" (Kajian etologis kebertahanan perempuan sebagai korban dalam lingkaran kekerasan). Konfrensi Internasional Feminisme: Persilangan Identitas, Agensi dan Politik (20 Tahun Jurnal Perempuan), 653-685. Jakarta: Yayasan Jurnal Perempuan.

Qonitatin, N., Widyawati, S., \& Asih, G. Y. (2011). Pengaruh katarsis dalam menulis ekspresif sebagai intervensi depresi ringan pada mahasiswa. Jurnal Psikologi Undip, 9(1), 21-32.

Saripah, I. (2010). Model konseling kognitif 
perilaku untuk menganggulangi bullying siswa (Studi pengembangan model konseling pada siswa sekolah dasar di beberapa kabupaten dan kota di Jawa Barat tahun ajaran 2008/2009). Proceedings of The 4th International Conference on Teacher Education; Join Conference UPI \& UPSI, 720-726. Retrieved from http://file.upi.edu/ Direktori/PROCEEDING/UPI-UPSI/

2010/ Book_4/ MODEL_
KONSELING_KOGNITIF_PERILAKU _UNTUK_MENANGGULANGI_BUL LYING_SISWA

Sawangchareon, K., Wattananukulkiat, S., Saito, A. S., Nanakorn, S., Doasodsai, S., Baba, M., \& Takemoto, H. (2013). The impact of counseling on the selfesteem of women in thailand who have experienced intimate partner violence. International Journal of Caring Sciences, 6(2), 243-251.

Shnabel, N., \& Ullrich, J. (2016). Putting emotion regulation in context: The (missing) role of power relations, intergroup trust, and groups' need for positive identities in reconciliation processes. Psychological Inquiry, 27(2), 124-132. doi: 10.1080/1047840x.2016. $\underline{1158538}$

Sulaeman, M. M. (2015). Resolusi konflik pendekatan ilmiah modern dan model tradisional berbasis pengetahuan lokal (Kasus di desa Gadingan kecamatan Sliyeg kabupaten Indramayu). Sosiohumaniora, 17(1), 41-48. doi: $\underline{10.1145 / 3132847.3132886}$

Talise, E. I. Y., Wijono, S., \& Hunga, I. (2016). Kebertahanan perempuan korban kekerasan dalam pacaran di kota Salatiga (Kajian psikoanalisa). Konfrensi Internasional Feminisme: Persilangan Identitas, Agensi dan Politik (20 Tahun Jurnal Perempuan), 511-538. Jakarta: Yayasan Jurnal Perempuan.
Tussey, B. E., Tyler, K. A., \& Simons, L. G. (2018). Poor parenting, attachment style, and dating violence perpetration among college students. Journal of Interpersonal Violence. doi: 10.1177/ $\underline{0886260518760017}$

Webel, C., \& Galtung, J. (2007). Handbook of peace and conflict studies. In Handbook of Peace and Conflict Studies. doi: 10.4324/9780203089163.ch24

Winch, G. (2017). Pertolongan pertama pada emosi anda. Jakarta: Gemilang.

Witte, T. H., Kopkin, M. R., \& Hollis, S. D. (2015). Is it dating violence or just "drunken behavior"? Judgments of intimate partner violence when the perpetrator is under the influence of alcohol. Substance Use and Misuse, 50(11), 1421-1426. doi: $\underline{10.3109 /}$ $\underline{10826084.2015 .1018539}$

World Health Organization. (2013). Global and regional estimates of violence against women: Prevalence and health effects of intimate partner violence and non-partner sexual violence. Retrieved February 22, 2019, from https://www.who.int/ reproductivehealth/publications/viole nce/9789241564625/en/

World Health Organization. (2017). Violence against women. Retrieved March 2, 2019, from website: https://www.who.int/news-room/factsheets/detail/violence-against-women

Yalch, M. M., Lannert, B. K., Hopwood, C. J., \& Levendosky, A. A. (2013). Interpersonal style moderates the effect of dating violence on symptoms of anxiety and depression. Journal of Interpersonal Violence, 28(16), 31713185. doi: $\underline{10.1177 / 0886260513496901}$

Yeo, A. (2002). Konseling: Suatu pendekatan pemecahan masalah. Jakarta: BPK Gunung Mulia. 